\title{
Effect of Fluoride Toxicity on Some Haematological Indices in Human Population
}

\author{
Sonali Dhawas ${ }^{1}$, Varsha Dhurvey ${ }^{2}$, Rashmi Urkude ${ }^{3}$ \\ ${ }^{1}$ Department of Zoology, Shri. S. S. Science and Comm. College, Ashti, Maharashtra, India \\ ${ }^{2}$ Department of Zoology, RTM Nagpur University, Nagpur, Maharashtra, India \\ ${ }^{3}$ Department of Chemistry, Shivaji Science College, Nagpur, Maharashtra, India
}

\begin{abstract}
Article Info

Volume 8, Issue 6

Page Number : $158-163$

Publication Issue

November-December-2021

Article History

Accepted : 01 Nov2021

Published :14 Nov2021

The present study aimed to determine the toxicity of Fluoride on haematological indices in some population residing in fluoride endemic area of Dongergaon village of Chandrapur district, Maharashtra, India. The study group was selected on the basis of elevated level of serum fluoride and symptoms of skeletal fluorosis. Various haematological parameters such as $\mathrm{Hb}$, TEC, TLC, HCT and PLT count were analysed. Statistical analysis was carried out and the result showed that values of haematological indices in study group were significantly declined as compared to control group. The outcomes of the present study indicated the reduction in Hb, TEC, HCT, increase in TLC and non-significant change in PLT.
\end{abstract}

Keywords : Fluoride, Human, Dongergaon, Maharashtra

\section{INTRODUCTION}

Fluoride is naturally occurring contaminant in the environment. In various regions of the world, high fluoride levels in drinking water poses a public health problem (Fawell et al, 2006) and extensive contamination of ground water by fluoride has been reported in India (Susheela 1999), where endemic fluorosis continues to be prevalent.

Fluoride is a ubiquitous element present in ground water, fluoridated foodstuffs, toothpaste and dentifrices lead to an excessive fluoride exposure in daily life (Barbier et al, 2011). Occurrence of fluoride in ground water has drawn worldwide attention due to its considerable impact on human physiology. Besides skeletal and dental tissues, high fluoride permeability is known to allow fluoride ion penetrate cell membranes and accumulate in diverse soft tissues such as stomach, small intestine, liver, kidney and brain, threatening the health of human and animal (Lech 2011).

Further investigation revealed bone and teeth especially are the sink for fluorosis but in addition to skeletal manifestations, chronic fluoride poisoning is known to cause a variety of pathological changes in non-skeletal or soft tissues (Teotia and Teotia 1991). 
Fluoride usually enters in blood circulation by absorption from duodenal and gastric mucosa via passive diffusion. It causes gastrointestinal damage, intermittent diarrhea, anorexia, flatulence, abdominal pain, constipation, nausea and loss of appetite (Sondhi et al, 1995; Shashi 1999; Susheela 2001 and Shashi et al, 2010). It affects the formation of blood forming cells i.e., hematopoietic cells in cavities of bone marrow (Choubisa et al, 1996 and Sanchez et al, 2013). Moreover, it also causes anaemia or premature erythrocyte deaths i.e. life span of RBCs decreases due to membrane degeneration that turns them into echinocytes (Shusheela and Moolenburgh 2001).

The deleterious effects of fluoride on blood have been studied well in different experimental models (Khandare et al, 2000; Cetin et al, 2004; Eren et al, 2005; Karadeniz and Altintas 2008 and Kant et al, 2009) but the studies which investigate the effects of fluoride on soft tissues and skeletal of human population did not report from Maharashtra and especially from study area which is fluoride contaminated (Kodate et al, 2016), population showed the symptoms of skeletal fluorosis (Dhawas et al, 2013) as well as food grown in study area also contains high amount of fluoride (Dhurvey and Dhawas, 2013., Dhurvey et al,2021). Therefore, the main objective of this investigation is to figure out the haematological effects of fluoride toxicity on human population residing in study area.

\section{MATERIALS AND METHODS}

\section{Study Area}

The Warora tehsil of Chandrapur district of Maharashtra is endemic for fluorosis showing high fluoride levels in drinking water and selection of Dongergaon village for present study from Warora tehsil was made on the basis of available information from our earlier ground water analysis which shows the high fluoride content in drinking water. It is located between $20 \mathrm{o} 21^{\prime} 33.4$ " $\mathrm{N}$ to $20 \mathrm{o} 19^{\prime} 45.9^{\prime \prime} \mathrm{N}$ latitudes and 790 02'04.8" E to 78o 57'35.7" E longitudes, covering an area 342.46 hectares.

\section{Selection of Study and Control Group}

Study group was selected on the basis of fluoride concentration in their serum samples and showed symptoms of skeletal fluorosis. The skeletal fluorosis was diagnosed clinically. The control group was selected from Warora city where water fluoride level in drinking water was below the permissible limit.

\section{Collection of Blood Samples}

After collection of those data, the blood samples were collected from the diagnosed cases of skeletal fluorosis and control group in non-reactive plastic vials and brought to the laboratory for further haematological analysis. The haematological indices studied in the collected samples of blood were Haemoglobin $(\mathrm{Hg})$, Total Erythrocytes Count (TEC), Total Leukocytes Count (TLC), Hematocrit (HCT) and Platelet Count (PLT).

The obtained values of various haematological indices were analyzed by comparing means and represented by Mean \pm SD. The data was analyzed by commercially available software package SPSS. The values considered significant were represented by an asterisk.

\section{RESULTS AND DISCUSSION}

The haematological analysis on blood samples of study group which show the elevated level of serum fluoride and symptoms of skeletal fluorosis of study area and control group were studied which includes Hg, TEC, TLC, HCT and PLT.

The results of the present study indicate that the Haemoglobin content in the blood samples of control 
group measured about $15.1 \pm 1.3$ which declined slightly to $11.0 \pm 1.8^{* *}$ in the study group as compared to control group as well as Total Erythrocytes Count measured about $5.3 \pm 0.6$ and it reduced to $3.6 \pm 0.7^{* *}$, Total Leukocytes Count measured about $8960 \pm 1414$ and it increased slightly to $11379 \pm 1489^{* *}$, the percentage of Hematocrit measured about $42.5 \pm 3.01$ and it reduced to $36.5 \pm 2.87^{* *}$ and the Platelet counts measured about $261.12 \pm 71.83$ and it reduced to $243 \pm$ 81.99 in the blood samples of control and study group respectively (Table 1).

A few reports are present in the literature of fluorotic anaemia. Though fluoride is capable of causing anaemia, the individuals nutritional status is also responsible for haemoglobin level. Bano et al, (1996) and Swarrup et al, (1998) reported the excessive intake of fluoride content reduced the level of haemoglobin concentration in their respective studies. The haematological analysis of present study also elucidated a decrease of total haemoglobin level in study group as compared to the control group. The findings could be collaborated with the reports of other workers in mammals (Shanthakumari and Subramanian 2007; Choudhary et al, 2012 and Atmaca et al, 2014). The possible explanation for this decrease is the lysis and lower production of RBCs due to decrease production of bone marrow result in anaemia and low haemoglobin production (Sayyed and Khan 2010).

Blood being most sensitive act as an indicator of countless metabolic disorders. The present study elucidated the significant decrease in the total erythrocytes count in study group as compared to control group. The findings on TEC is in agreement with the reports of Mohiuddin and Reddy (1989) who reported a reduction of RBC count in sheep, Saxena et al, (2001) in Fish and Shanthakumari and Subramanian (2007) in Rats. However, in contrast Gujarathi et al, (1991) reported increase in TEC in buffalo calves. As well as in the present study the total leukocytes counts increases in study group as compared to control group. Similar results have been reported by Sharma et al, (2006) and (2008). This increase in leukocytes suggests that fluoride as a foreign body may evoke the immune response through the lymphocytes, which is more prone to the fluoride and comes in action as its rapid increasing number suggests. Maheswaran et al, (2008) reported that the increased in WBC count might be due to the tissue damage i.e. stimulation of the immune system caused by sodium fluoride. The contradictory findings are reported by Das et al, (2006) where significant reduction in Neutrophil and Monocytes in rats exposed to fluorides for 28 days is observed and they concluded that these effects would lead to lowered cellular immunity.

The hematocrit also recognized as an erythrocyte volume fraction (EVF) or packed cell volume (PCV) is the volume percentage (\%) of RBCs in blood. The present study elucidated the significant decrease in the percentage of hematocrit in study group as compared to control group. Similar results are reported by Swarup and Singh (1989) in cattle and Gujrathi et al, (1991) in buffaloes during Fluorosis. In the present study the platelet counts shows nonsignificant decrease in study group as compared to control group. The results are in good agreement with findings of Sharma et al, (2010) where they cleared it may be due to bone marrow suppression.

Our present findings concords with many previous studies on various experimental animals. The interaction of toxic substance fluoride with various haematological parameters alters its normal physiology. The erythrocytes count decreases which may affect their $\mathrm{Hb}$ carrying capacity, consequently lowering $\mathrm{Hb}$ content and haematocrit. A nonsignificant change in platelets count and increase in leukocytes which might be due to the tissue damage. 
TABLE 1. Different Haematological indices in control and study groups with Fluoride intoxication

\begin{tabular}{|c|c|c|c|}
\hline S. N. & Parameters & Group & Mean \pm SD \\
\hline \multirow{2}{*}{1} & Haemoglobin $(\mathrm{gm} \%)$ & Control & $15.1 \pm 1.3$ \\
\cline { 3 - 4 } & \multirow{2}{*}{2} & Study & $11.0 \pm 1.8^{* *}$ \\
\hline \multirow{2}{*}{3} & \multirow{2}{*}{ Total Erythrocytes Count (mill/Cumm) } & Control & $5.3 \pm 0.6$ \\
\cline { 3 - 4 } & & Study & $3.6 \pm 0.7^{* *}$ \\
\hline \multirow{2}{*}{4} & \multirow{2}{*}{ Hematocrit $(\%)$} & Control & $8960 \pm 1414$ \\
\cline { 3 - 4 } & & Study & $11379 \pm 1489^{* *}$ \\
\hline \multirow{2}{*}{5} & \multirow{2}{*}{ Total Platelets (thousand/Cumm) } & Control & $42.5 \pm 3.01$ \\
\cline { 3 - 4 } & & Study & $36.5 \pm 2.87^{* *}$ \\
\cline { 3 - 4 } & & Control & $261.12 \pm 71.83$ \\
\hline
\end{tabular}

$(* * \mathrm{p}<0.01, \mathrm{n}=100)$

[2]. Bano, R., Sachdev, S., Lall, S. B. (1996).

\section{CONCLUSION}

Thus, it is concluded that fluoride concentration above the permissible limit in drinking water causes various harmful effects on population residing in the study area. There is an urgent need of fluoride free drinking water supply, defluoridation of currently available water sources and their constant monitoring as well as awareness about deleterious effects of fluoride toxicity.

\section{ACKNOWLEDGEMENT}

The authors grateful to Dr. Jaya Kodate, Assistant Professor, Geology and Mrs. Bharati Sable, Pathologist for their valuable guidance and also acknowledge the help of villagers, village sarpunch and staff of rural PHC of Dongergaon for their co-operation in the conduct of this study.

\section{REFERENCES}

[1]. Atmaca, N. et al., (2014). Effect of resveratrol on hematological and biochemical alterations in rats exposed to fluoride. BioMed. Res. Int.
Biochemical changes in the testes of swiss albino mice exposed to chronic ingestion of sodium fluoride. Ind. J. Environ. \& Toxicol, 6(1):19-21.

[3]. Barbier, O., Arreola-Mendoza, L., Del Razo, L. M. (2011). Molecular mechanisms of fluoride toxicity. Chem. Biol. Interact, 188:319-333.

[4]. Cetin, N. et al., (2004). Effect of fluoride application on some blood parameters in rabbits. EUJ. Health Sci, 13:46-50.

[5]. Choubisa, S. et al., (1996). Prevalence of fluorosis in some villages of Dungarpur district of Rajasthan. Indian J. Environ. Health, 38(2):119-126.

[6]. Choudhary, A., Parihar, S., Kasim, M. (2012). High fluoride concentration and amelioration effect in haematological parameter after supplementary diet aloe vera in albino rat (Rattus norvegicus). Bio. Front, 5(2-I):130-136.

[7]. Das, S., Maiti, R., Ghosh, D. (2006). Fluorideinduced immunotoxicity in adult male albino rat: a correlative approach to oxidative stress. J. Immunotoxicol, 3(2):49-55.

[8]. Dhawas, S., Dhurvey, V., Kodate, J., Urkude, R. (2013). An epidemiological study of skeletal fluorosis in some villages of chandrapur district, 
Maharashtra, India. J. Environ. Res. Develop, 7(4A):1679-1683.

[9]. Dhurvey, V. and Dhawas, S. (2014). Skeletal Fluorosis in relation to drinking water, nutritional status and living habits in rural areas of Maharashtra, India. IOSR-JESTFT, 8(1):6367.

[10]. Dhurvey, V., Karim, F., Dhawas, S., Urkude, R and Katke, S. (2021). Fluoride accumulation in foodstuff and dietary intake in a fluorideendemic area of Chandrapur district, Maharashtra. Vidyabharati Inter. Inter. Res. J, 13(1):105-109.

[11]. Eren, E., Ozturk, M., Mumcu, E. F., Canatan, D. (2005). Fluorosis and its hematology effects. Toxicol. Ind. Health, 21(10):255-258.

[12]. Fawell, J., Bailey, K., Chilton, J., Dahi, E., Fewtrell, L., Magara, Y. (2006). Fluoride in drinking water. IWA, London, UK. World Health Organization.

[13]. Gujarathi, S., Bhoop, S., Bhikane, A. (1991). Effect of acute experimental fluorine poisoning on hematological and biochemical indices in buffalo calves (Buhalus huhalis). Indian J. Vet. Med, 11:80-82.

[14]. Kant, V. et al., (2009). Haematological profile of subacute oral toxicity of fluoride and ameliorative efficacy of aluminium sulphate in goats. Toxicol. Int, 31.

[15]. Karadeniz, A., Altintas, L. (2008). Effects of panax ginseng on fluoride-induced haematological pattern changes in mice. Fluoride, 41(1):67.

[16]. Khandare, A. L., Kumar, P. U., Lakshmaiah, N. (2000). Beneficial effect of tamarind ingestion on fluoride toxicity in dogs. Fluoride, 33(1):3338.

[17]. Kodate, J., Marganwar, R., Dhurvey, V., Dhawas, S., Urkude, R. (2016). Assessment of groundwater quality with special emphasis on fluoride contamination in some villages of
Chandrapur district of Maharashtra, India. IOSR-JESTFT, 10(3):15-26.

[18]. Lech, T. (2011). Fatal cases of acute suicidal sodium and accidental zinc fluorosilicate poisoning. Review of acute intoxications due to fluoride compounds. For. Sci. Inter, 206:20-24.

[19]. Maheswaran, R. et al., (2008). Haematological studies of freshwater fish: clarias batrachus (L.) exposed to mercuric chloride. Int. J. Integr. Biol, 2(1):49-54.

[20]. Mohiuddin, S. M., Reddy, M. V. (1989). Haematological and biochemical studies on fluoride toxicity in sheep. Ind. Vet. J, 66:10891091.

[21]. Santoyo-Sanchez, M. P. et al., (2013). Effects of acute sodium fluoride exposure on kidney function: water homeostasis, and renal handling of calcium and inorganic phosphate. Biol. Trace Elem. Res, 152(3):367-372.

[22]. Saxena, R., Gupta, R., Tripathi, M. M., Krishna, G. (2001). Fluoride induced heamatological alteration in the fresh water fish Channa punctatus. J. Eco-Physio Occupl. Health, 1(12):139-146.

[23]. Sayyed, M. A., Khan, S. A. (2010). Effect of acute fluoride intoxication on some hematological changes in chicken (Gallus domesticus). Biol (PAKISTAN), 56 (1 \& 2):123127.

[24]. Shanthakumari, D., Subramanian, S. (2007). Effect of fluoride intoxication on bone tissue of experimental rats. Res. J. Environ. Sci, 1:82-92.

[25]. Sharma, J. D., Solanki, D., Solanki, M. (2008). Amelioration of fluoride toxicity in rats through vitamins $(\mathrm{C}, \mathrm{D})$ and calcium. Toxicol. Int, 15(2):111-116.

[26]. Sharma, J. D., Solanki, M., Agrawal, P., Solanki, D. (2006). Effect of fluoridated water on blood physiology of albino rats (Rattus norvegicus). Environ. Degrad. \& Manag, 2:13-17.

[27]. Sharma, S. et al., (2010). Comparative study on acute toxicity of fluoride: aluminium and 
aluminium fluoride to swiss albino mice. Australas. J. Ecotoxicol, 16(1):41-47.

[28]. Shashi, A. (1999). Gastric lesions in experimental fluorosis. Asian J. Microbiol. Biotech. Environ. Sci, 1:171-175.

[29]. Shashi, A., Sharma, N., Bhardwaj, M. (2010). Pathological evaluation of pancreatic exocrine glands in experimental fluorosis. Asian Pac. J. Trop. Med, 3(1):36-40.

[30]. Shusheela, A. K., Moolenburgh, H. C. (2001). Treatise on fluorosis. Fluoride. 34:181-183.

[31]. Sondhi, H., Gupta, M. L., Gupta, G. L. (1995). Intestinal effects of sodium fluoride in swiss albino mice. Fluoride, 28(1):21-24.

[32]. Susheela, A. K. (1999). Fluorosis management programme in India. Curr. Sci, 77:1250-1256.

[33]. Susheela, A. K. (2001). A treatise on fluorosis. Copyright Prop. (Dr.) A.K. Susheela, Director, Fluorosis research and Rural Development Foundation. 92:1-119.

[34]. Swarrup, D., Dwivedi, S. K., Dey, S., Ray, S. K. (1998). Fluoride intoxication in bovines due to industrial pollution. Ind. J. Anim. Sci, 68(7):605-608.

[35]. Swarup, D., Singh, Y. (1989). Bovine fluorosis in a brick kiln congested zone. Indian J. Vet. Med, 9(1):12-14.

[36]. Teotia, S. P. S., Teotia, M. (1991). Endemic fluoride: Bone and teethupdate. Ind. J. Environ. Toxicol, 1:1-6.

\section{Cite this article as :}

Sonali Dhawas, Varsha Dhurvey, Rashmi Urkude, "Effect of Fluoride Toxicity on Some Haematological Indices in Human Population", International Journal of Scientific Research in Science and Technology (IJSRST), Online ISSN : 2395-602X, Print ISSN : 23956011, Volume 8 Issue 6, pp. 158-163, NovemberDecember 2021. Available at doi : https://doi.org/10.32628/IJSRST21866 Journal URL : https://ijsrst.com/IJSRST21866 